\title{
SPATIAL AND TEMPORAL VARIATION OF DISSOLVED OXYGEN AND ECOSYSTEM ENERGETICS IN DEVILS HOLE, NEVADA
}

\author{
Melody J. Bernot ${ }^{1,3}$ and Kevin P. Wilson ${ }^{2}$
}

\begin{abstract}
Devils Hole, a unique ecosystem in the Mojave Desert, is home to a few dominant species of algae and invertebrates as well as the endangered Devils Hole pupfish, Cyprinodon diabolis. With consistently high water temperature $\left(33.5^{\circ} \mathrm{C} / 93^{\circ} \mathrm{F}\right.$ ) and low dissolved oxygen $\left(\mathrm{O}_{2}\right)$ concentration (about $2.5 \mathrm{mg} \mathrm{O}_{2} \cdot \mathrm{L}^{-1}$ ), organisms are at the extremes of their physiological limits, and production of $\mathrm{O}_{2}$ by microbial biofilms is essential to ecosystem stability. Water column $\mathrm{O}_{2}$ concentrations were measured from July 2008 to March 2010 in the deep pool and shallow shelf habitats of Devils Hole to quantify variability in $\mathrm{O}_{2}$ concentrations and ecosystem metabolism rates. Benthic $\mathrm{O}_{2}$ dynamics were also measured in microbial biofilms using microelectrode surveys. Water column $\mathrm{O}_{2}$ ranged from 2 to $6 \mathrm{mg} \mathrm{O} \mathrm{O}_{2} \cdot \mathrm{L}^{-1}$ in summers and from 1.5 to $2.2 \mathrm{mg} \mathrm{O}_{2} \cdot \mathrm{L}^{-1}$ in winter across the deep pool and shallow shelf habitats. Primary production ranged from 4 to $21 \mathrm{mg} \mathrm{O} \cdot \mathrm{L}^{-1} \mathrm{~d}^{-1}$, with a significant decline over the study period, potentially due to a change in the microbial biofilm community. Respiration ranged from 1.5 to $9.7 \mathrm{mg} \mathrm{O}_{2} \cdot \mathrm{L}^{-1} \mathrm{~d}^{-1}$ and showed a significant increase over time. Within microbial biofilms, $\mathrm{O}_{2}$ ranged from 0 to $76 \mathrm{mg} \mathrm{O}_{2} \cdot \mathrm{L}^{-1}$. Higher concentrations of $\mathrm{O}_{2}$ produced by these microbial biofilms may be due to improved photosynthetic efficiency under limited sunlight exposure. Autotrophic biofilms had higher $\mathrm{O}_{2}$ concentrations during direct light exposure than during indirect light exposure. In contrast, heterotrophic biofilms had similar $\mathrm{O}_{2}$ concentrations regardless of light exposure. Because microbial biofilms are important components of this unique ecosystem, shifts in their composition or activity may threaten ecosystem stability by reducing background $\mathrm{O}_{2}$ concentrations below the physiological limits of the endangered Devils Hole pupfish and the entire biotic community.
\end{abstract}

Resumen._La Garganta del Diablo (Devils Hole), un ecosistema único en el Desierto de Mojave, es el hogar de algunas especies dominantes de algas e invertebrados, así como también del pez Cyprinodon diabolis, que se encuentra en peligro de extinción. Con temperaturas elevadas constantes del agua $\left(33.5^{\circ} \mathrm{C} / 93{ }^{\circ} \mathrm{F}\right)$ y bajas concentraciones de oxígeno disuelto $\left(\mathrm{O}_{2}\right)\left(\sim 2.5 \mathrm{mg} \mathrm{O}_{2} \cdot \mathrm{L}^{-1}\right)$, los organismos se encuentran en sus límites fisiológicos superiores y la producción de $\mathrm{O}_{2}$ por parte de las biopelículas microbianas es fundamental para la estabilidad del ecosistema. Desde julio de 2008 a marzo de 2010 se midieron las concentraciones de $\mathrm{O}_{2}$ en la columna de agua, en las pozas profundas y en hábitats superficiales de la Garganta del Diablo, para determinar la variabilidad en las concentraciones de $\mathrm{O}_{2}$ y las tasas metabólicas del ecosistema. También se midió la dinámica bentónica del $\mathrm{O}_{2}$ en las biopelículas microbianas mediante el uso de microelectrodos. El $\mathrm{O}_{2}$ de la columna de agua varió de 2 a $6 \mathrm{mg} \mathrm{O}{ }_{2} \cdot \mathrm{L}^{-1}$ en verano y de 1.5 a $2.2 \mathrm{mg} \mathrm{O}_{2} \cdot \mathrm{L}^{-1}$ en invierno en pozas profundas y en los hábitats superficiales. La productividad primaria varió de 4 a $21 \mathrm{mg} \mathrm{O} \mathrm{O}_{2} \cdot \mathrm{L}^{-1} \mathrm{~d}^{-1}$ con una disminución significativa durante el período de estudio, posiblemente debido al cambio en la comunidad de biopelículas microbianas. La respiración varió de 1.5 a $9.7 \mathrm{mg} \mathrm{O}_{2} \cdot \mathrm{L}^{-1} \mathrm{~d}^{-1}$ y aumentó significativamente con el tiempo. En las biopelículas microbianas, el $\mathrm{O}_{2}$ varió de 0 a $76 \mathrm{mg} \mathrm{O} \mathrm{O}_{2} \cdot \mathrm{L}^{-1}$. Las concentraciones más elevadas de $\mathrm{O}_{2}$ que estas biopelículas microbianas produjeron podría deberse a una mejora en la eficiencia fotosintética bajo una limitada exposición a la luz del sol. Las biopelículas autótrofas tuvieron concentraciones más elevadas de $\mathrm{O}_{2}$ durante la exposición directa a la luz en comparación con la exposición indirecta, a diferencia de las biopelículas heterótrofas que tuvieron concentraciones de $\mathrm{O}_{2}$ similares, sin importar la exposición a la luz. Debido a que las biopelículas microbianas son componentes importantes de este ecosistema único, los cambios en su composición o actividad pueden amenazar la estabilidad del ecosistema al reducir las concentraciones subyacentes de $\mathrm{O}_{2}$ por debajo de los límites fisiológicos del pez de la Garganta del Diablo que se encuentra en peligro de extinción, y de toda la comunidad biótica.

Ecosystem energetics in desert springs are typically dominated by autotrophic processes in the form of $\mathrm{O}_{2}$ production by primary producers (algae). These energetics are less influenced by heterotrophic processes including respiration or consumption of $\mathrm{O}_{2}$ by bacteria and other heterotrophs (e.g., Grimm and Fisher 1984,
Wilson and Blinn 2007). However, measurements in desert springs are limited, with most studies conducted in lotic ecosystems. Further, the temporal variability of energetics in desert spring ecosystems is not well understood.

Devils Hole is a unique ecosystem nestled in one of the most extreme North American 
deserts, the Mojave, and this desert spring is the sole habitat for the critically endangered Devils Hole pupfish (Cyprinodon diabolis). A fissure formed in Paleozoic times, Devils Hole acts as part of a subterranean drainage network of groundwater in this arid ecosystem (Riggs and Deacon 2005). Devils Hole water is characterized by supersaturated calcium carbonate concentrations, high water temperatures $\left(33.5^{\circ} \mathrm{C}\right)$, and low ambient dissolved oxygen concentrations (about $2.5 \mathrm{mg} \mathrm{O}_{2} \cdot \mathrm{L}^{-1}$ ). Groundwater entering the Devils Hole ecosystem is remarkably stable and acts to buffer the ecosystem from sources of variation (e.g., seasonal physiochemical variation).

Despite these extreme physiochemical parameters, Devils Hole is home to approximately 80 species of algae (Shepard et al. 2000) and 15 macroinvertebrates (Herbst and Blinn 2003) in addition to Devils Hole pupfish, the only vertebrate. The unique flora and fauna of Devils Hole are at the extremes of their physiological limits for survival and reproduction and must compete for limited available resources (Wilson and Blinn 2007). Overall, organismal diversity in Devils Hole is low, which is typical of thermal aquatic habitats (Naiman 1976, Wilson and Blinn 2007). Dominant algal species include cyanobacteria (primarily Chroococcus spp. and Oscillatoria spp.), diatoms (Denticula sp.), and filamentous Spirogyra (Shepard et al. 2000). Dominant macroinvertebrates include an amphipod (Hyalella sp.), a spring snail (Tryonia variegata), 2 beetle species (Stenelmis calida, Neoclypeodytes cinctellus), and dipterans (Herbst and Blinn 2003). The small (<30 mm) and short-lived (12-14 months) endemic Devils Hole pupfish was listed as endangered in 1967. Population estimates have not exceeded about 530 individuals since counts began, and monthly population counts in the early 1970 s yielded an average of about 200 individuals. For unknown reasons, the Devils Hole population began declining in the early 1990s, and current population estimates indicate only 50-100 adults remain. Annual population cycles indicate peak populations occur in summer (Jul-Oct) after spawning in spring (Mar-Jun; Riggs and Deacon 2005). Reasons for the most recent decline have not yet been determined, but several hypotheses have been put forward. The hypotheses that are most pertinent to this current study include continuing water decline due to increased groundwater mining (Riggs and Deacon 2005, Deacon et al. 2007), declining solar radiation or allochthonous nutrients (Wilson and Blinn 2007), increasing water temperature due to climate change (Threloff and Manning 2003), and shifts in algal/microbial community states that result in shifts in dissolved oxygen (Riggs and Deacon 2005). Anthropogenic influences can thus affect physiochemical parameters (e.g., temperature, $\mathrm{O}_{2}$ ) and food resources (e.g., algae) that are undoubtedly fundamental properties governing Devils Hole pupfish populations. Although the Devils Hole pupfish lives in a habitat with low ambient $\mathrm{O}_{2}$ concentrations, the fish has no accessory respiratory structures to make use of atmospheric oxygen (Behnke 1981). Helfman et al. (1997) states that certain species of desert pupfishes can live in habitats with as little as $0.13 \mathrm{mg} \mathrm{O}_{2} \cdot \mathrm{L}^{-1}$, which is the lowest recorded concentration for fishes without respiratory accessories. Pupfishes have also been documented living in habitats with temperatures from near freezing in winter to $44{ }^{\circ} \mathrm{C}$ in summer (the Cottonball Marsh pupfish; Feldmeth 1981). However, it is less clear how life history traits such as egg hatching success and larvae survival are affected at temperatures $>37^{\circ} \mathrm{C}$ (Kinne and Kinne 1962).

Dissolved $\mathrm{O}_{2}$ in Devils Hole is regulated by ambient $\mathrm{O}_{2}$ concentrations coupled with metabolism rates (photosynthesis and respiration) of both the algal and microbial communities. The algal and microbial communities also regulate basal resource availability (i.e., food) for the Devils Hole pupfish (Minckley and Deacon 1975, Wilson and Blinn 2007). Further, the algal community provides a majority of the carbon input into the ecosystem via autochthonous production during the summer months (Wilson and Blinn 2007), and the microbial community may degrade more recalcitrant allochthonous carbon and inputs (e.g., organic matter including but not limited to leaves, seeds, stems, insects, owl pellets, rodent droppings, and debris from storm runoff) for ingestion by invertebrates and/or pupfish. Because of the vital role physiochemical parameters and basal resources (algae and sediment microbes) play in maintaining a suitable environment for pupfish, dissolved $\mathrm{O}_{2}$ assessments must be coupled with an increased understanding of ecosystem energetics (i.e., 
production and respiration) so that managers can make better decisions regarding recovery efforts for the Devils Hole pupfish.

The objectives of this research were (1) to document spatial and temporal variability of dissolved oxygen in Devils Hole microbial biofilms and (2) to quantify ecosystem energetics (gross primary production and ecosystem respiration) to assess changes over time. We present a novel assessment of oxygen dynamics using a 3-year data set of continuous oxygen measurements coupled with benthic oxygen microelectrode surveys. Currently, there have been few assessments (Shepard et al. 2000, Herbst and Blinn 2003, Wilson and Blinn 2007) of the physiochemical dynamics within the water column of Devils Hole or within the microbial biofilms, despite their likely importance to pupfish survival and reproduction. Further, to our knowledge, these data are the first multiyear assessment of ecosystem energetics in this unique ecosystem.

\section{Methods}

\section{Study Site}

Devils Hole is separated from the contiguous Death Valley National Park and is located in Ash Meadows National Wildlife Refuge in southern Nye County, Nevada, USA $\left(36^{\circ} 26^{\prime} \mathrm{N}\right.$, $\left.116^{\circ} 17^{\prime} \mathrm{W}\right)$. Devils Hole is a limnocrene, located approximately $15 \mathrm{~m}$ below the land surface, where groundwater is exposed, forming a small aquatic habitat approximately 3.5 $\times 22 \mathrm{~m}$. Within this area lies a "shallow shelf" near the southern end of the pool (approximately $2.6 \times 6.1 \mathrm{~m}$; Fig. 1 ). This shallow shelf is seasonally covered by both autotrophic and heterotrophic microbial biofilms. The pool extends to an unknown depth $>150 \mathrm{~m}$ (Riggs and Deacon 2005) and receives $<5$ hours of direct sunlight only during summer. The shallow shelf has an average depth of about $0.3 \mathrm{~m}$ and receives 4-5 hours of direct sunlight during summer and only indirect light during winter (Wilson 2001). A majority of Devils Hole pupfish feeding and spawning occurs on the shelf where microbial biofilm growth is substantial.

\section{Oxygen Measurements}

$\mathrm{O}_{2}$ concentrations $\left(\mathrm{mg} \mathrm{O} \mathrm{O}_{2} \cdot \mathrm{L}^{-1}\right)$ and temperature $\left({ }^{\circ} \mathrm{C}\right)$ were logged using YSI Water Quality Sonde Model 6600V2-4 at 15-minute intervals from July 2008 to March 2010 in both the shallow shelf habitat (southern end at $5 \mathrm{~cm}$ above substrate) and deep pool habitat (at $5 \mathrm{~m}$ depth, $5 \mathrm{~cm}$ above substrate). Sonde exchange, as described by Wagner et al. (2006), was followed due to the harsh environmental conditions frequently encountered at the Devils Hole site (e.g., air temperature routinely exceeds $45^{\circ} \mathrm{C}$ ), which can interfere with calibration accuracy. Sondes were exchanged at both sites every 14 days with recalibrated instruments, such that individual sondes were rotated over the sampling period. Calibration protocols also included temperature validation conducted by placing sondes into a water bath simultaneously and validating sonde temperature against an NIST thermometer to within $0.2{ }^{\circ} \mathrm{C}$. A full record of deployment details, possible biofouling, calibration checks, routine station and instrument maintenance, and repair history was maintained for each sonde.

Oxygen sensors were calibrated according to YSI specifications. Sondes were equipped with the YSI Rapid Pulse system that utilized a Clark-type sensor similar to membrane-covered steady-state DO probes. One-point calibrations were conducted at $100 \%$ saturation during each calibration and potential drift was assessed. Calibrations were compensated for temperature and barometric pressure per standard techniques. Biofouling and instrument drift were checked by deploying a recently calibrated sonde next to the sonde being removed and assessing sensor equipment. Biofouling throughout the study period was minimal, though it accounted for loss of $\mathrm{O}_{2}$ data on 26 days over the study period. Data from these days were eliminated from all analyses.

\section{GPP and ER Calculations}

Oxygen measurements at 15-minute intervals were used to calculate net ecosystem metabolism (primary production and respiration). Instantaneous metabolism was calculated based on change in $\mathrm{O}_{2}$ concentrations (oxygen evolved during photosynthesis and removed during respiration) while accounting for the reaeration flux of oxygen with the atmosphere (sensu Cole et al. 2000). Because direct measurements of reaeration flux were not possible, reaeration was estimated using the Bayesian metabolic model (BaMM) for simultaneous quantification of reaeration and metabolism (Holtgrieve et al. 2010). Specifically, 10 days 


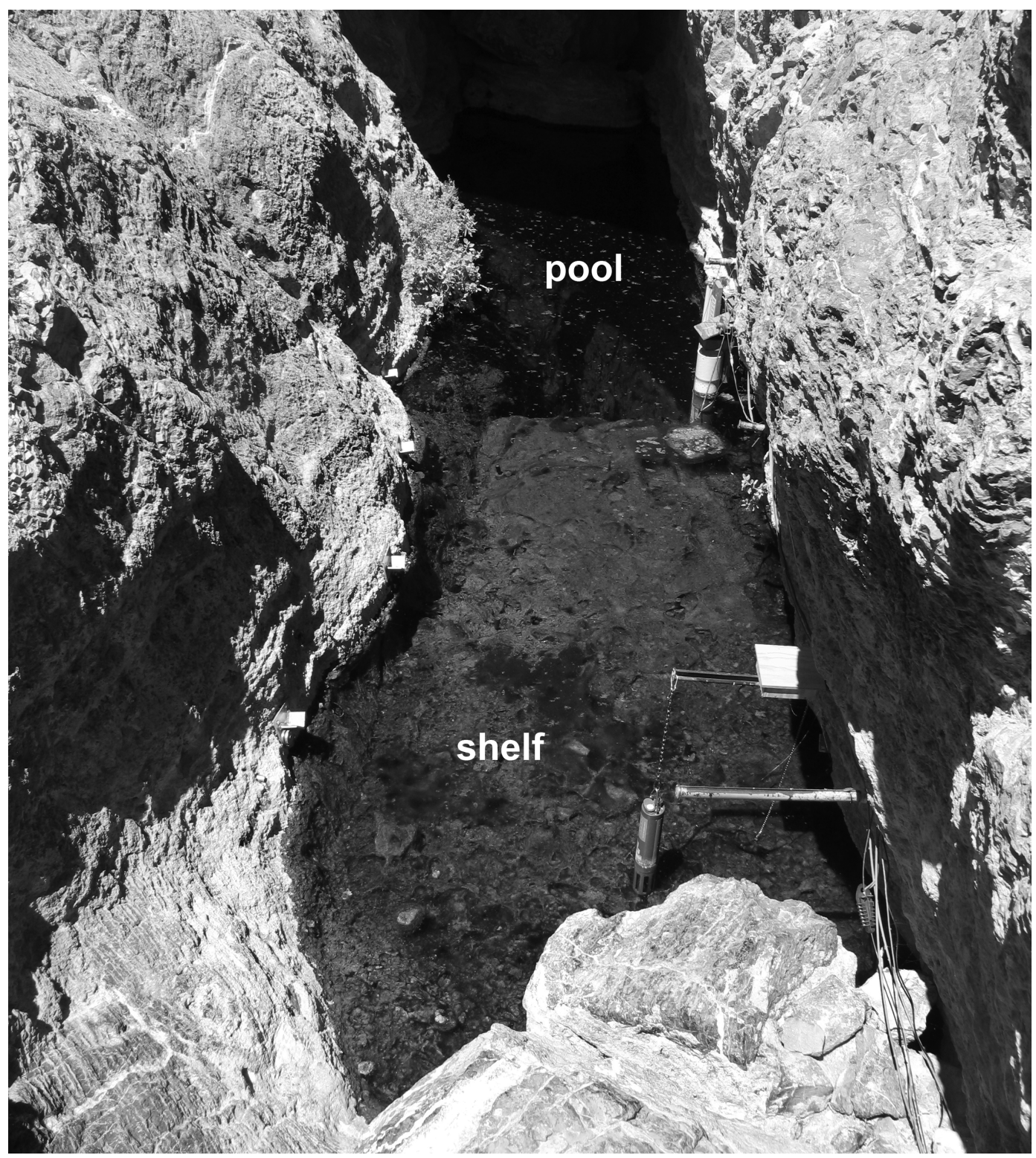

Fig. 1. The Devils Hole ecosystem in Death Valley National Park, Nevada, USA. Shallow shelf and deep pool habitats are noted.

over the study period, spanning all years and seasons, were randomly selected for analysis via BaMM. For each day, BaMM was used to fit observed variation in $\mathrm{O}_{2}$ concentrations to the model and develop initial estimates of $\mathrm{O}_{2}$ reaeration. The 10-day time period for assessment was selected to provide a period with minimal changes in the ecosystem, thus providing a stable equilibrium consistent with the model assumptions. Once model fit was achieved, the initial reaeration estimate was challenged by altering the $\mathrm{O}_{2}$ reaeration flux by $1 \%, 2 \%$, and $5 \%$. For each day and each trial, best model fit was achieved with a reaeration flux estimate of $0.0012 \mathrm{~d}^{-1}$. Model fit was not achieved when reaeration was challenged with adjusted estimates. Therefore, the reaeration flux rate of $0.0012 \mathrm{~d}^{-1}$ was applied for all 
metabolism estimates. Because reaeration is both low and static in this environment, error associated with model estimates is likely minimal (Holtgrieve et al. 2010). BaMM techniques are not suitable for continuous estimates of metabolism over time due to the assumption of a static system (i.e., no seasonal change); thus, instantaneous and daily metabolic rates were subsequently calculated for each day ( $n=739$ daily shallow shelf estimates; $n=872$ daily deep pool estimates) sensu Cole et al. (2000) using the $\mathrm{O}_{2}$ reaeration flux calculated with BaMM.

\section{Microelectrode Measurements}

Benthic microelectrode surveys were conducted in July 2009 and 2010 using cathodetype dissolved $\mathrm{O}_{2}$ microelectrodes (OX-500, Unisense, Aarhus N, Denmark; Revsbech and Jørgensen 1986, Kemp and Dodds 2001) during periods of indirect light (10:00-12:40) and direct light (13:30-15:20) in the shallow shelf habitat of Devils Hole. A total of $16 \mathrm{O}_{2}$ profiles within the microbial biofilm were measured in direct light, and a total of $16 \mathrm{O}_{2}$ profiles were measured in the shelf habitat during indirect light in both 2009 and 2010. Profiles measured during indirect light periods were not in the exact same position as profiles measured during direct light periods, though the same biofilm type and general location (where possible) was replicated in both sampling periods. No microelectrode surveys were conducted in the pool habitat. Microbial biofilms were classified as autotrophic or heterotrophic depending on the dominant organisms. Autotrophic biofilms were primarily composed of filamentous Spirogyra spp. and blue-green cyanobacteria. Heterotrophic biofilms consisted of sediment, senescing biofilm, and some Beggiatoa mats. Microelectrodes were calibrated immediately prior to and following all sampling events (within 48 hours). We used a 2-point calibration with $\mathrm{N}_{2}$-saturated water and air-saturated water prepared as endpoints, and we simultaneously measured with a microelectrode $(\mathrm{mV})$ and handheld YSI dissolved $\mathrm{O}_{2}$ meter $\left(\mathrm{mg} \mathrm{O}_{2} \cdot \mathrm{L}^{-1}\right)$. To ensure microelectrodes were linear over the range of field data recorded, subsequent calibrations were conducted using a 6-point calibration curve (0-60 mg $\left.\mathrm{O}_{2} \cdot \mathrm{L}^{-1}\right)$, employing $\mathrm{O}_{2}$-saturated water and Winkler titrations. During microelectrode surveys, $\mathrm{O}_{2}$ concentrations were measured in the water column, at the biofilm-water interface, and every $100 \mu \mathrm{m}$ into the biofilm until bedrock was reached. Field reference measurements of $\mathrm{O}_{2}$ concentrations were collected as simultaneous measurements of $\mathrm{O}_{2}$ using a handheld YSI $\mathrm{O}_{2}$ probe and a microelectrode, to ensure that no matrix effects or microelectrode drift occured during field sampling. Bulk water $\mathrm{pH}$, temperature, and dissolved $\mathrm{O}_{2}$ were also measured at each biofilm site with standard YSI handheld meters.

\section{Statistics}

Differences in mean $\mathrm{O}_{2}$ concentration (mean for all $\mathrm{O}_{2}$ measurements over the course of the study period) between the shallow shelf and deep pool habitats were compared using a paired $t$ test. Changes in daily GPP and ER rates over time in the deep pool and shallow shelf habitat were analyzed using analysis of variance (ANOVA). Differences in $\mathrm{O}_{2}$ dynamics (mean, minimum, and maximum concentrations and slope of change in the biofilm) among biofilm types and light periods (direct versus indirect light) were compared using ANOVA. All statistical analyses were performed using SAS Statistical Software (SAS Institute ${ }^{\circledR}$ 9.2, 2002-2008, Cary, NC).

\section{RESUlTS}

Over the study period, water column $\mathrm{O}_{2}$ ranged from 1.9 to $6.5 \mathrm{mg} \mathrm{O}_{2} \cdot \mathrm{L}^{-1}$ on the shallow shelf $\left(\bar{x}=3.0 \mathrm{mg} \mathrm{O}{ }^{2} \cdot \mathrm{L}^{-1}\right)$ and from 1.9 to $2.8 \mathrm{mg} \mathrm{O}_{2} \cdot \mathrm{L}^{-1}$ in the deep pool $(\bar{x}=$ $\left.2.7 \mathrm{mg} \mathrm{O}_{2} \cdot \mathrm{L}^{-1}\right)$. Mean water column $\mathrm{O}_{2}$ concentrations in the deep pool were significantly different from those in the shallow shelf habitat $(n=399, t=-26.96, P<0.01)$. Deep pool $\mathrm{O}_{2}$ varied $<2 \%$ over the study period and shallow shelf $\mathrm{O}_{2}$ varied approximately $67 \%$ over the study period (Fig. 2). Seasonal increases in mean daily $\mathrm{O}_{2}$ concentrations associated with primary production were only observed in the shallow shelf habitat during periods of direct light (spring and summer; Fig. 3).

Consistent with low variation in water column $\mathrm{O}_{2}$ concentrations, the deep pool habitat had lower ecosystem metabolism relative to the shallow shelf habitat (Fig. 4). Specifically, gross primary production (GPP) in the deep pool $\left(0.5-6.7 \mathrm{mg} \mathrm{O}_{2} \cdot \mathrm{L}^{-1} \mathrm{~d}^{-1} ; \bar{x}=1.7 \mathrm{mg} \mathrm{O}_{2}\right.$. $\left.\mathrm{L}^{-1} \mathrm{~d}^{-1}\right)$ was significantly lower $(\sim 32 \%)$ than 


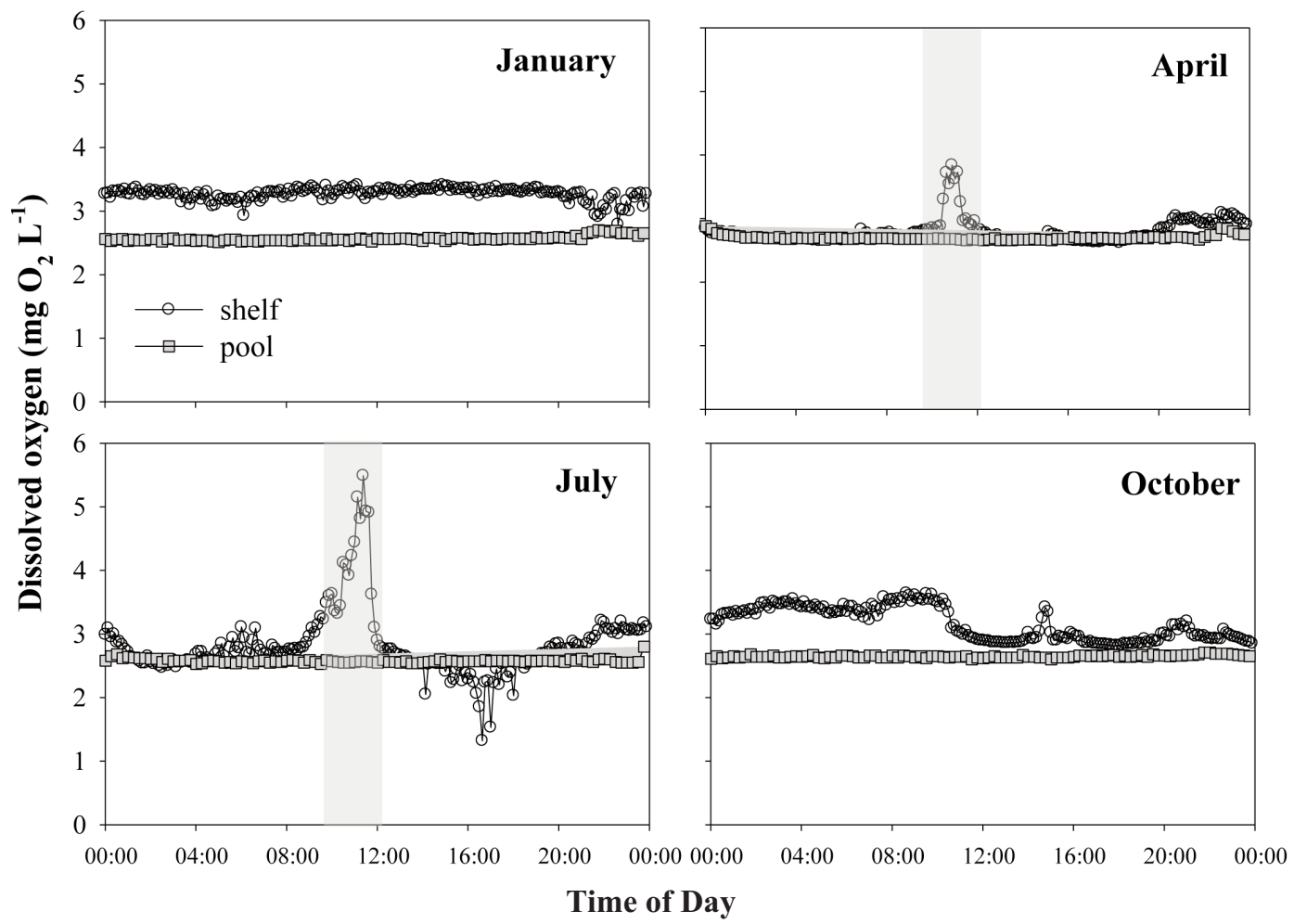

Fig. 2. Diurnal variation in dissolved oxygen $\left(\mathrm{O}_{2}\right)$ concentrations in Devils Hole, Nevada, for selected days in January (1 Jan 2009), April (1 Apr 2009), August (1 Aug 2009), and October (1 Oct 2009). Data are shown for the shallow shelf and deep pool habitats. Shading denotes periods of direct light on the shallow shelf of Devils Hole.

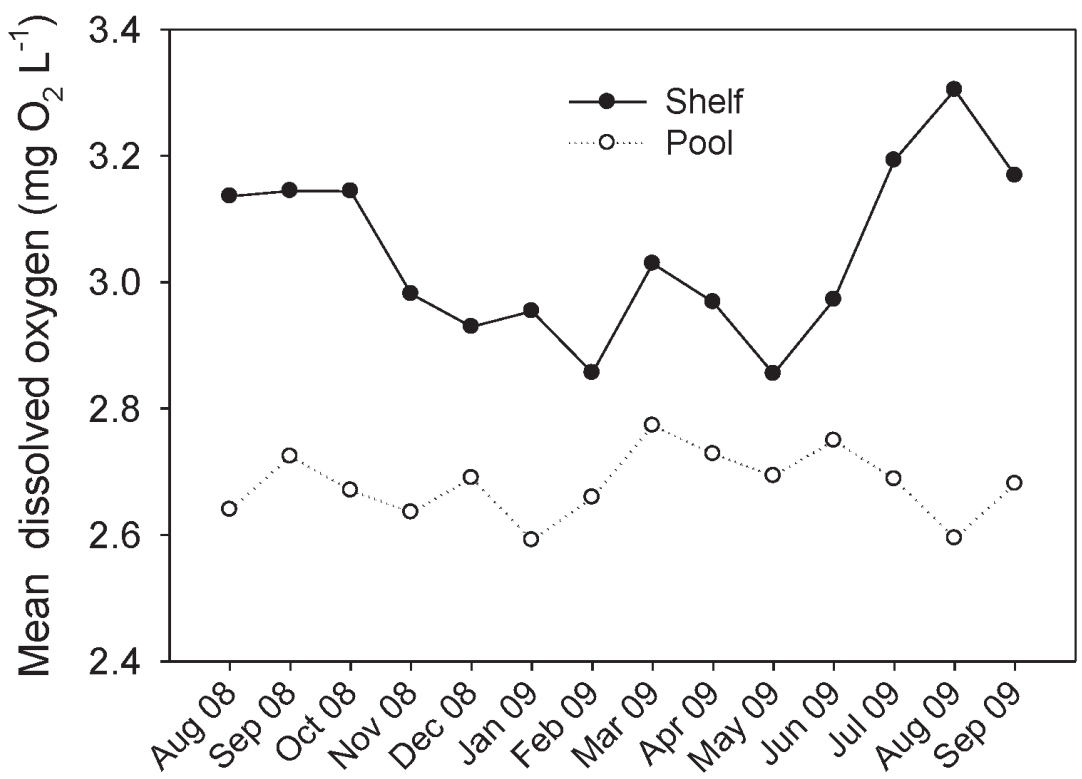

Fig. 3.Variation in mean dissolved oxygen $\left(\mathrm{O}_{2}\right)$ concentrations in the shallow shelf and deep pool habitats of Devils Hole, Nevada. Values are mean concentrations for each month. 

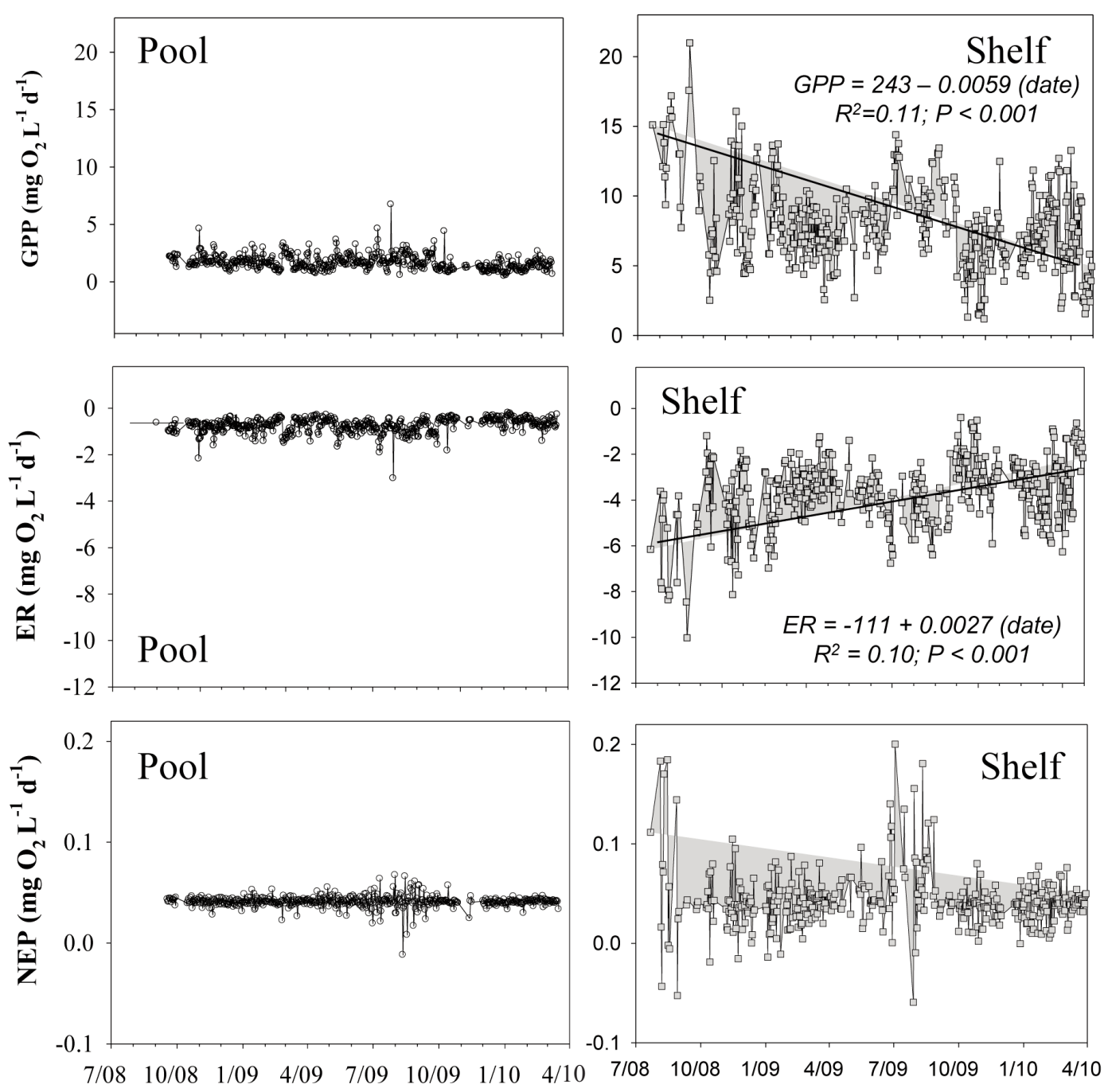

Fig. 4. Variation in daily gross primary production (GPP), ecosystem respiration (ER), and net ecosystem productivity (NEP) from July 2008 to March 2010 in the shallow shelf and deep pool habitats of Devils Hole, Nevada.

GPP on the shallow shelf $\left(1.2-21.9 \mathrm{mg} \mathrm{O} \mathrm{O}_{2}\right.$. $\mathrm{L}^{-1} \mathrm{~d}^{-1}, \bar{x}=7.8 \mathrm{mg} \mathrm{O} \cdot \mathrm{L}^{-1} \mathrm{~d}^{-1} ; n=399$ on the shallow shelf, $t=38.44, P<0.01)$. Rates of ecosystem respiration (ER) were also significantly greater and more variable in the shallow shelf habitat $\left(-0.4\right.$ to $-10.1 \mathrm{mg} \mathrm{O}_{2}$. $\left.\mathrm{L}^{-1} \mathrm{~d}^{-1}\right)$ than in the deep pool habitat $(-0.2$ to $-3.1 \mathrm{mg} \mathrm{O} \cdot \mathrm{L}^{-1} \mathrm{~d}^{-1} ; n=399, t=-37.91, P<$ 0.01). Both the deep pool and the shallow shelf habitat were net autotrophic over the study period (with the exception of $2 \mathrm{~d}$ in the deep pool habitat and $11 \mathrm{~d}$ in the shallow shelf habitat that had a net consumption of $\mathrm{O}_{2}$ ), with an average $\mathrm{P}: \mathrm{R}$ ratio of 2.7 in the deep pool and 3.0 on the shallow shelf. Overall, GPP decreased over the study period $(F=$ 50.78, $\mathrm{df}=398, P<0.01)$ and ER increased over the study period $(F=45.85, \mathrm{df}=398, P$ $<0.01)$ in the shallow shelf habitat, but no temporal trends were observed in the deep pool habitat (Fig. 4).

Benthic dissolved $\mathrm{O}_{2}$ concentrations (as measured with microelectrodes) in autotrophic biofilms ranged from 0 to $76.0 \mathrm{mg} \mathrm{O}_{2} \cdot \mathrm{L}^{-1}$ during direct light exposure and from 0 to 8.4 $\mathrm{mg} \mathrm{O}_{2} \cdot \mathrm{L}^{-1}$ during indirect light exposure (Fig. 5). Maximum $\mathrm{O}_{2}$ concentrations were measured at an average depth of $675 \mu \mathrm{m}$ 


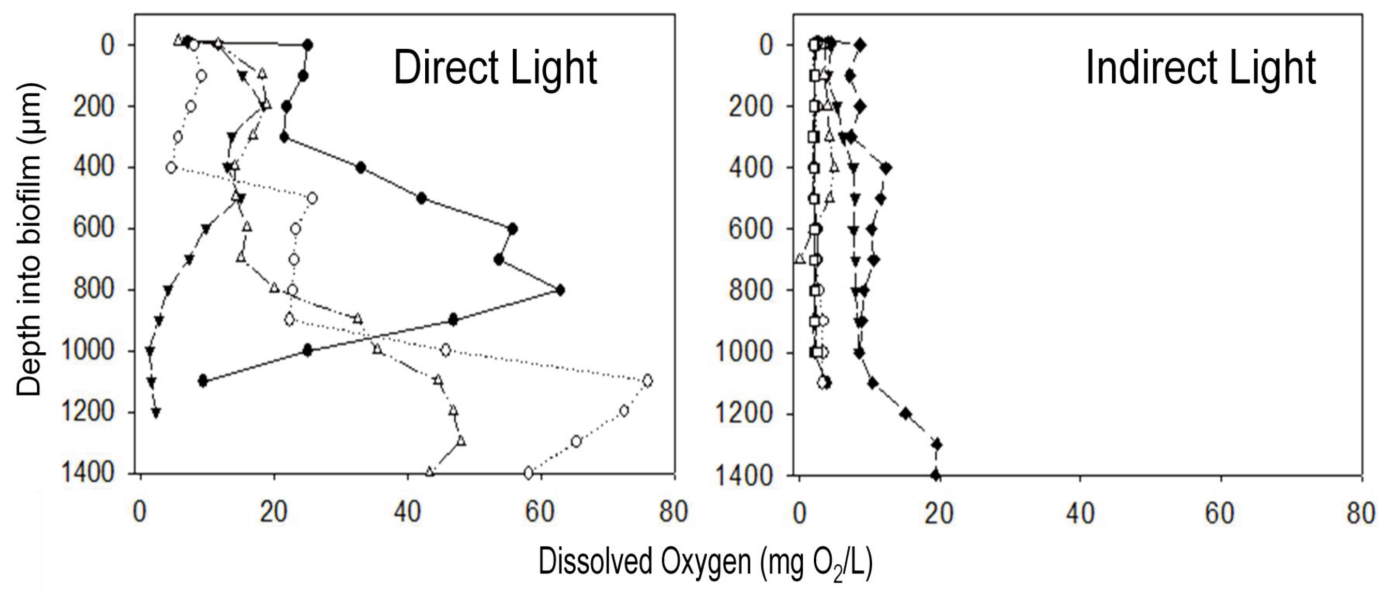

Fig. 5. Spatial variation of dissolved oxygen $\left(\mathrm{O}_{2}\right)$ concentration within autotrophic biofilms during periods of direct and indirect light. Each line represents an individual microelectrode profile with a random subset of profiles depicted.

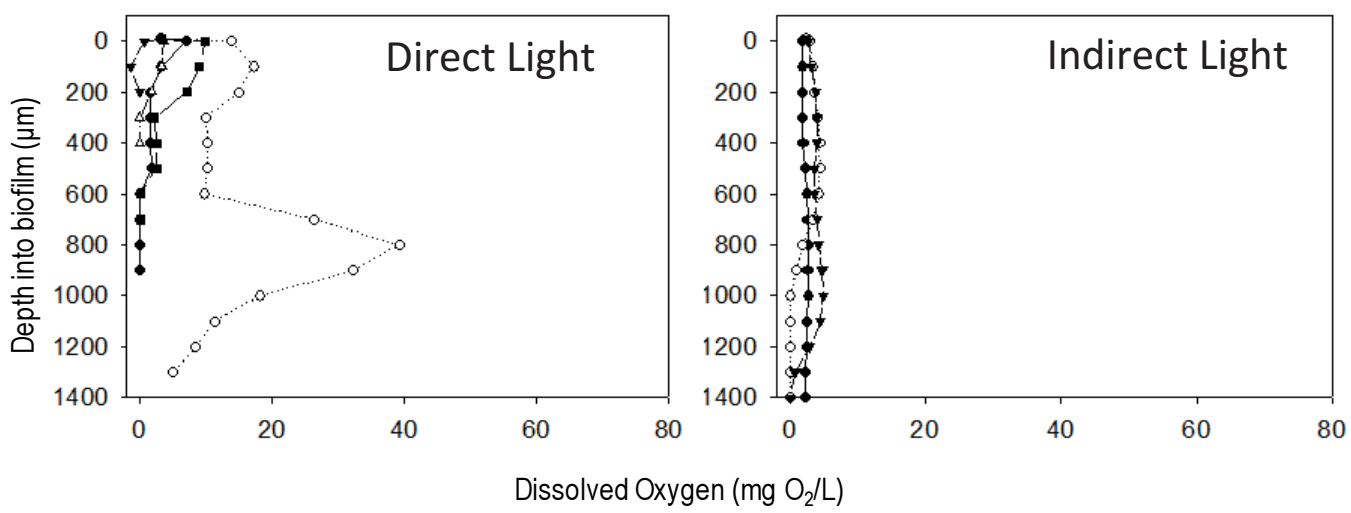

Fig. 6. Spatial variation of dissolved oxygen $\left(\mathrm{O}_{2}\right)$ concentration within heterotrophic biofilms during periods of direct and indirect light, Devils Hole, Nevada. Each line represents an individual microelectrode profile with a random subset of profiles depicted.
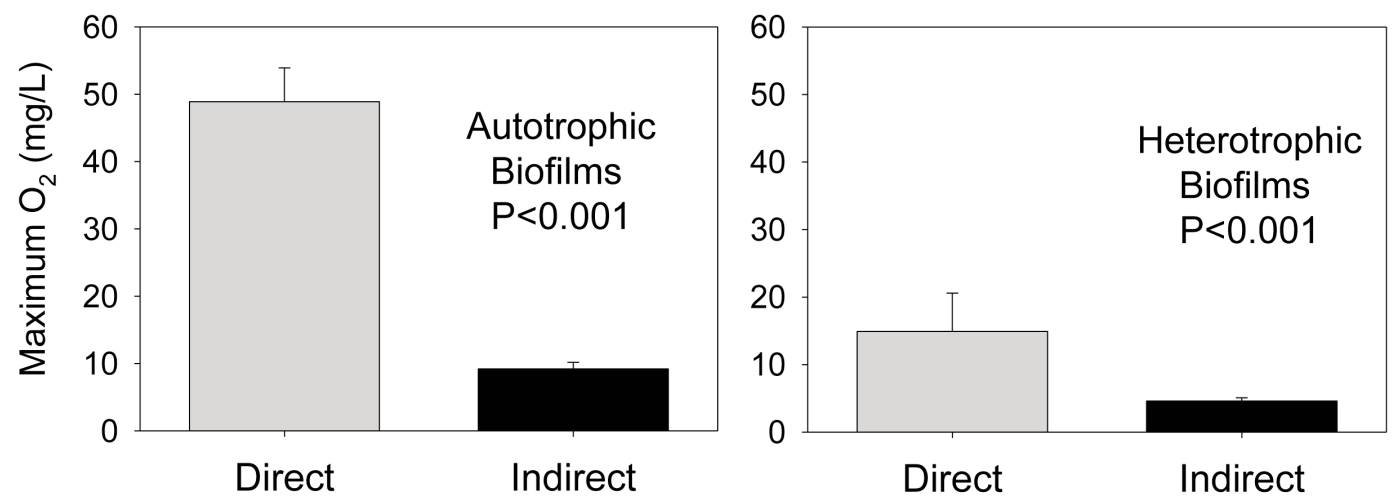

Fig. 7. Differences in maximum dissolved oxygen $\left(\mathrm{O}_{2}\right)$ concentrations in autotrophic and heterotrophic biofilms during periods of indirect and direct light. For each bar, $n=32$, and one standard deviation is shown. 
TABLE 1. Gross primary production (GPP) and ecosystem respiration (ER) rates in Devils Hole compared to other aquatic ecosystems. Data presented are ranges of estimates. An asterisk (*) denotes that data are not available

\begin{tabular}{lccl}
\hline System & $\mathrm{GPP}\left(\mathrm{mg} \mathrm{O}_{2} \cdot \mathrm{L}^{-1} \mathrm{~d}^{-1}\right)$ & $\mathrm{ER}\left(\mathrm{mg} \mathrm{O}_{2} \cdot \mathrm{L}^{-1} \mathrm{~d}^{-1}\right)$ & Reference \\
\hline Devils Hole & $1.5-23$ & $0.7-10.2$ & This study \\
Devils Hole (chambers) & $6-246$ & $*$ & Wilson and Blinn 2007 \\
Thermal stream & $7.5-12$ & $*$ & Naiman 1976 \\
Lakes & $0.03-36.3$ & $0.03-37.3$ & Duarte and Agusti 1998 \\
Rivers & $0.02-36.6$ & $0.12-42$ & Duarte and Agusti 1998 \\
Marine coastal & $0-69.5$ & $0-20.7$ & Duarte and Agusti 1998 \\
Estuarine marshes & $3.7-16.3$ & $2-12.6$ & Duarte and Agusti 1998 \\
Open sea & $0-12.7$ & $0-2.29$ & Duarte and Agusti 1998 \\
\hline
\end{tabular}

below the sediment-water interface in autotrophic biofilms. During direct light periods, $\mathrm{O}_{2}$ dynamics within autotrophic biofilms were spatially variable. In contrast, little variability in biofilm $\mathrm{O}_{2}$ dynamics was observed during indirect light. Benthic dissolved $\mathrm{O}_{2}$ in heterotrophic biofilms ranged from 0 to $39.0 \mathrm{mg}$ $\mathrm{O}_{2} \cdot \mathrm{L}^{-1}$ during direct light exposure and from 0 to $6.1 \mathrm{mg} \mathrm{O}_{2} \cdot \mathrm{L}^{-1}$ during indirect light exposure (Fig. 6). Maximum $\mathrm{O}_{2}$ concentrations were measured at an average depth of $233 \mu \mathrm{m}$ below the sediment-water interface in heterotrophic biofilms. Autotrophic biofilms had higher $\mathrm{O}_{2}$ concentrations during direct light exposure relative to indirect light exposure $(t=6.32, \mathrm{df}=8, P=0.001)$, in contrast to heterotrophic biofilms, which had similar $\mathrm{O}_{2}$ concentrations regardless of light exposure $(P$ $>0.05$; Fig. 7).

\section{Discussion}

Dissolved $\mathrm{O}_{2}$ concentrations in the water column of Devils Hole have spatial and temporal variation consistent with other freshwater ecosystems (e.g., Kemp and Dodds 2001, Bernot et al. 2010). This variation yields distinct diurnal and seasonal changes associated with light availability and autotrophic activity. Further, estimates of GPP and ER in Devils Hole are comparable to previous studies in freshwater ecosystems (Table 1). However, based on the extensive algal biofilms on the shallow shelf of Devils Hole and previous estimates of GPP in Devils Hole (Wilson and Blinn 2007), we hypothesized that GPP in Devils Hole would be significantly higher relative to other freshwater ecosystems, though this was not the case (Table 1). Interestingly, previous GPP estimates in Devils Hole using benthic chambers (Wilson and Blinn 2007) found that GPP ranged an order of magnitude greater than estimates based on the diurnal $\mathrm{O}_{2}$ change measured in this current study (Table 1). This inconsistency is likely due to the differences in techniques employed to estimate GPP. Benthic chambers allowed for the high production within the autotrophic biofilms to be captured in GPP estimates. The high benthic $\mathrm{O}_{2}$ concentrations $\left(\sim 76 \mathrm{mg} \mathrm{O}_{2} \cdot \mathrm{L}^{-1}\right.$; Fig. 4) measured in this current study are consistent with an order-of-magnitude increase in GPP estimates. It is likely that much of the $\mathrm{O}_{2}$ produced in the autotrophic biofilms of Devils Hole does not diffuse to the water column where monitoring probes were located, thus accounting for the underestimate of GPP rates in this study.

In productive months, thermal streams have significant spatial variation in primary productivity due to algal mat differences in physiological states (e.g., growth, slough, drift) (Naiman 1976). In Devils Hole, there was significant spatial variation in benthic $\mathrm{O}_{2}$ concentrations within both autotrophic and heterotrophic biofilms (Figs. 4, 5). For example, maximum concentrations in heterotrophic biofilms exceeded $39 \mathrm{mg} \mathrm{O}_{2} \cdot \mathrm{L}^{-1}$ (Fig. 5) and were potentially generated by diatoms living in consortia with heterotrophic organisms. Further, benthic $\mathrm{O}_{2}$ concentrations within autotrophic biofilms ranged from 0 to $76 \mathrm{mg} \mathrm{O}_{2} \cdot \mathrm{L}^{-1}$ (Fig. 4). Maximum $\mathrm{O}_{2}$ concentration in autotrophic biofilms was about 10X saturation (saturation @ $7.8 \mathrm{mg} \mathrm{O}_{2} \cdot \mathrm{L}^{-1}$ at specific temperature and barometric pressure of Devils Hole) during periods of direct sunlight. Previous measurements of $\mathrm{O}_{2}$ concentrations in freshwater microbial biofilms have documented only about 2X saturation (e.g., Paerl and Ustach 1982, Kemp and Dodds 2001). However, $\mathrm{O}_{2}$ concentrations in water can theoretically exceed $100 \mathrm{X}$ equilibrium solubility (Bowers et al. 1995). 
The high concentrations of $\mathrm{O}_{2}$ produced by autotrophic biofilms during direct light may be a result of an adapted, more efficient photosynthetic response to the brief periods of direct light this habitat receives. This idea is further supported by the steep slope of $\mathrm{O}_{2}$ concentrations within the autotrophic biofilms during direct light, which indicates greater rates of $\mathrm{O}_{2}$ production. Despite supersaturated $\mathrm{O}_{2}$ concentrations within microbial biofilms during direct light periods, dissolved $\mathrm{O}_{2}$ concentrations in the water column decrease. This decrease is likely a function of the increase in temperature accompanying this period and may prevent $\mathrm{O}_{2}$ from staying in a dissolved state.

Despite the limited direct light the Devils Hole ecosystem receives, the system is net autotrophic (Fig. 4). Stockner (1967) similarly measured a P:R ratio of 3.7 for Ohanapecosh Hot Springs, Washington. Although aquatic ecosystems typically respire more energy than is produced by autochthonous sources $(\mathrm{P}: \mathrm{R}<$ 1; Hynes 1972), most systems rely heavily on allochthonous energy sources derived from their watersheds. Allochthonous input into Devils Hole is limited to windblown organic matter from the surrounding desert landscape and rare flood events. Wilson and Blinn (2007) estimated that $60 \%$ of the total energy to the food web of Devils Hole was in the form of allochthonous carbon. In comparison, Naiman (1976) quantified that $11,065 \mathrm{kcal} \cdot \mathrm{m}^{-2}$ annual input of energy to a Mojave Desert thermal stream was completely accounted for by autochthonous primary production, with the bulk of annual primary production $(81 \%)$ channeled into respiration and decomposers. Because of the isolation of production in the benthos, it is likely that only a small fraction of GPP in Devils Hole is allotted to invertebrates and the pupfish, though changes in autotrophic production may still decrease availability of food and/or habitat.

Recent studies have anecdotally suggested that food availability for pupfish has likely declined, resulting in decreased success of individuals (Riggs and Deacon 2005). However, the absolute biomass of algae has not declined, as recent estimates indicate greater algal biomass in 2009 relative to measurements in 1999 and 2001 (K. Wilson, unpublished data). Rather, it is thought that the algal community has shifted to comprise a greater proportion of unicellular cyanobacteria and diatoms, potentially due to changes in nutrient availability (National Park Service, unpublished data). In the late 1960s, analysis of pupfish stomach contents indicated primary consumption of the green alga Spirogyra (Minckley and Deacon 1975). In contrast, analysis of stomach contents in 1999 and 2000 indicated greater pupfish consumption of diatoms $(14.6 \%$ of stomach contents) and filamentous cyanobacteria ( $\sim 1 \%$ stomach contents), particularly in summer (Wilson and Blinn 2007). Because diatoms and cyanobacteria provide less energy per unit mass relative to green algae (Stockner and Porter 1988), this shift in basal resource use may be negatively affecting pupfish survival and recruitment. Although Spirogyra was abundant in microbial mats of Devils Hole, particularly in summer, its abundance relative to diatoms and cyanobacteria appears to be declining. Estimates of GPP and ER in this study identified a decreasing trend in GPP and an increasing trend in ER (Fig. 4), supporting a potential shift in the benthic microbial community. However, an understanding of why the benthic microbial community may be shifting is still lacking. If food availability acts to regulate the size of the Devils Hole pupfish population on an annual basis under natural conditions, small changes in the productivity of the system would likely immediately result in fewer Devils Hole pupfish.

The Devils Hole pupfish feed and spawn primarily within the microbial biofilms on the shallow shelf. Physiochemical parameters (e.g., $\mathrm{pH}$, temperature, $\mathrm{O}_{2}$ ) and food resources (e.g., microbial biofilms) are undoubtedly fundamental properties governing Devils Hole pupfish populations. Specifically, algal production has a strong influence on $\mathrm{O}_{2}$ availability in the low-oxygen environment of the Devils Hole ecosystem, particularly in the benthic habitat. Because pupfish respond not only to the absolute concentrations of $\mathrm{O}_{2}$ but also to the variability in concentrations (Gustafson and Deacon 1997), successful management of pupfish recruitment demands a more comprehensive understanding of dissolved $\mathrm{O}_{2}$ dynamics within this unique ecosystem. This void in our understanding must be addressed in order for managers to make more-informed management decisions about the Devils Hole ecosystem and to foster Devils Hole pupfish population recovery to historical levels. 


\section{ACKNOWLEDGMENTS}

We thank Bailey Gaines of Death Valley National Park (Pahrump, NV), Matt Beer, Joe Meiring, and Maria Dzul for laboratory and field assistance; Walter Dodds for equipment; National Science Foundation IDBR \#1011787, Ball State University, and the National Park Service for funding; and 2 anonymous reviewers for helpful comments on the manuscript.

\section{Literature Cited}

BEHNKe, R.J. 1981. Systematic and zoogeographical interpretation of Great Basin trouts. Pages 95-124 in R.J. Naiman and D.L. Soltz, editors, Fishes in North American deserts. John Wiley \& Sons, New York, NY. Bernot, M.J., D.J. Sobota, R.O. Hall, P.J. Mulholland, W.K. Dodds, J.R. Webster, J.L. TANK, L.R. AshKeNAS, L.W. COOPER, C.N. DaHM, ET AL. 2010. Interregional comparison of land-use effects on stream metabolism. Freshwater Biology 55:1874-1890.

Bowers, P.G., C. Hofstetter, C.R. Letter, and R.T. ToOmeY. 1995. Supersaturation limit for homogeneous nucleation of oxygen bubbles in water at elevated pressure: "Super-Henry's Law." Journal of Physical Chemistry 99:9632-9637.

Cole, J.J., M.L. Pace, S.R. Carpenter, and J.F. KitCHELl. 2000. Persistence of net heterotrophy in lakes during nutrient addition and food web manipulations. Limnology and Oceanography 45:1718-1730.

Deacon, J.E., A.E. Williams, C.D. Williams, and J.E. WiLLiams. 2007. Fueling population growth in Las Vegas: how large-scale groundwater withdrawal could burn regional biodiversity. BioScience 57: 688-698.

FELDMETH, C.R. 1981. The evolution of thermal tolerance in desert pupfish (genus Cyprinodon). Pages 357384 in R.J. Naiman and D.L. Soltz, editors, Fishes in North American deserts. John Wiley \& Sons, New York, NY.

Grimm, N.B., AND S.G. Fisher. 1984. Exchange between interstitial and surface water: implications for stream metabolism and nutrient cycling. Hydrobiologia 111: 219-228.

Gustafson, E.S., AND J.E. Deacon. 1997. Distribution of larval Devils Hole pupfish, Cyprinodon diabolis Wales, in relation to dissolved oxygen concentration in Devils Hole. Unpublished report prepared for the National Park Service, Death Valley National Park. Contract No. 1443PH13095341. 61 pp.

Helfman, G.S., B.B. Collete, and D.E. Facey. 1997. The diversity of fishes. Blackwell Science, Malden, MA. 528 pp.

Herbst, D.B., AND D.W. Blinn. 2003. Devils Hole benthic invertebrate community dynamics: distribution, seasonality, and production. Sierra Nevada Aquatic Research Laboratory Report, University of California, Natural Reserve System. 7 March 2003.

Holtgrieve, G.W., D.E. Schindler, T.A. Branch, and Z.T. A'MAR. 2010. Simultaneous quantification of aquatic ecosystem metabolism and reaeration using a Bayesian statistical model of oxygen dynamics. Limnology and Oceanography 55:1047-1063.
HynEs, H.B.N. 1972. The ecology of running waters. University of Toronto, Toronto, Ontario, Canada. $555 \mathrm{pp}$.

Kemp, M.J., And W.K. DodDs. 2001. Centimeter-scale patterns of dissolved oxygen concentrations and nitrification rates in prairie stream substrata. Journal of the North American Benthological Society 20: 347-357.

KinNE, O., AND E.M. KINNE. 1962. Effects of salinity and oxygen on development rates in a cyprinodont fish. Nature 193:1097-1098.

Minckley, C.O., and J.E. Deacon. 1975. Foods of the Devils Hole pupfish, Cyprinodon diabolis (Cyprinodontidae). Southwestern Naturalist 20:105-111.

Naiman, R.J. 1976. Primary production, standing stock, and export of organic matter in a Mohave Desert thermal stream. Limnology and Oceanography 21: 60-73.

Paerl, H.W., and J.F. Ustach. 1982. Blue-green algal scums: an explanation for their occurrence during freshwater blooms. Limnology and Oceanography 27:212-217.

Revsbech, N.P., And B.B. Jørgensen. 1986. Microelectrodes: their use in microbial ecology. Advanced Microbial Ecology 9:293-352.

Riggs, A.C., AND J.E. DEACON. 2005. Connectivity in desert aquatic ecosystems: the Devils Hole story. Conference Proceedings. Spring-fed Wetlands: Important Scientific and Cultural Resources of the Intermountain Region, 2002; [cited 12 April 2008]. Available from: http://www.wetlands.dri.edu

Shepard, W.D., D.W. Blinn, R.J. Hoffman, and P.T. KANTZ. 2000. The algae of Devils Hole, Nevada, Death Valley National Park. Western North American Naturalist 60:410-419.

Stockner, J.G. 1967. The ecology of the Ohanapecosh Hot Springs, Mount Rainier National Park, Washington. Doctoral dissertation, University of Washington, Seattle, WA. 232 pp.

Stockner, J.G., AND K.G. Porter. 1988. Microbial food webs in freshwater planktonic ecosystems. Pages 69-83 in S.R. Carpenter, editor, Complex interactions in lake communities. Springer-Verlag.

Threloff, D., AND L. Manning. 2003. Thermal environment of the Devils Hole pupfish (Cyprinodon diabolis). National Park Service Report, Death Valley National Park.

Wagner, R.J., R.W. Boulger Jr., C.J. Oblinger, and B.A. Sмiтн. 2006. Guidelines and standard procedures for continuous water-quality monitors: station operation, record computation, and data reporting. U.S. Geological Survey Techniques and Methods 1D3, U.S. Geological Survey, Reston, VA.

WiLSON, K.P. 2001. Role of allochthonous and autochthonous carbon in the food web of Devils Hole, Nevada. Master's thesis, Department of Biological Sciences, Northern Arizona University, Flagstaff, AZ. $58 \mathrm{pp}$.

WiLSON, K.P., AND D.W. BLINN. 2007. Food web structure, energetics, and importance of allochthonous carbon in a desert cavernous limnocrene: Devils Hole, Nevada. Western North American Naturalist 67: 185-198.

Received 26 August 2011 Accepted 26 April 2012 